Spring 2018

\title{
The Proportional Representation Debate at the Constitutional Convention: Why the Nationalists Lost
}

John Patrick Coby

Smith College, pcoby@smith.edu

Follow this and additional works at: https://scholarworks.smith.edu/gov_facpubs

Part of the Political Science Commons

\section{Recommended Citation}

Coby, John Patrick, "The Proportional Representation Debate at the Constitutional Convention: Why the Nationalists Lost" (2018). Government: Faculty Publications, Smith College, Northampton, MA.

https://scholarworks.smith.edu/gov_facpubs/6 


\title{
The Proportional Representation Debate at the Constitutional Convention: Why the Nationalists Lost
}

\author{
JOHN PATRICK COBY
}

\begin{abstract}
Representation in the national legislature, whether proportionate to people or equal for all states, was the signature issue of the Constitutional Convention of 1787. The resulting Great Compromise was the signature achievement. This article argues that the nationalists' loss on proportional representation cannot be explained simply as a pragmatic accommodation in the face of obdurate opposition by small-state delegations. Such obduracy existed, and it mattered. But it was met by obduracy in kind and in defense of a position that was inherently stronger. Why then did the nationalist coalition fail? It failed, the article contends, because, in addition to the opposition it encountered and the tactical mistakes it made, the three-part argument it mounted logically required that the states be abolished and the regime founded be a democracy. The large-state nationalists yielded in the end because they were not consolidationists and not democrats.
\end{abstract}

One great anomaly of the American political system is that the principle of one person, one vote applies only to half of the legislative branch. In the Senate each state is equally represented no matter its size. Thus Wyoming, with a population under 600,000, has the same senatorial representation as California, with a population over 38,000,000. Sixty-five times more populous is California than Wyoming, and yet they both send two senators to Washington.

The story of the Constitutional Convention and of the Great Compromise that made representation in the lower house proportional and in the upper house equal has been told many times before. What is intended here is not a retelling

John Patrick Coby is Esther Booth Wiley 1934 Professor of Government at Smith College, Seelye Hall, Northampton, MA 01063 (pcoby@smith.edu).

I wish to thank the journal's anonymous referees for their many insightful comments.

American Political Thought: A Journal of Ideas, Institutions, and Culture, vol. 7 (Spring 2018).

2161-1580/2018/0702-0002 $\$ 10.00$. @ 2018 by The Jack Miller Center. All rights reserved. 
of that story, but rather an attempt to explain why it came to pass that the largestate nationalists, united on the issue of proportionality, suffered so devastating a defeat, notwithstanding the fact that they began the Convention with the votes to prevail. Since the article's focus is the nationalist case for proportional representation, the case made by the opposition-small-state localists and states' rights advocates, called here "confederalists" for want of a more accurate and simpler name ${ }^{1}$ - will not receive comparable attention. ${ }^{2}$

In the winter/spring of 1787, with the Constitutional Convention approaching in May, James Madison penned letters to Thomas Jefferson (March 19), Edmund Randolph (April 8), and George Washington (April 16) (Madison 1975, 317-22, 368-71, 382-88). In all three letters Madison expressed confidence that the Convention would accept proportional representation of states in the national legislature, even though states were currently represented equally in the Confederation Congress and would be so again at the Convention. His optimism rested on the following calculation: "The change in the principle of representation will be relished by a majority of the States, and those too of most influence. The northern States will be reconciled to it by the actual superiority of their populousness; the Southern by their expected superiority on this point" (371). The states of the Deep South—North Carolina, South Carolina, and Georgia-had experienced rapid population growth in the 1780 s, and they fully expected that

1. While "confederal" was a term in currency at the time, "confederalist," as far as I can determine, was not. It is offered here as a counterpart to "nationalist." Of course, there were no formal parties at the Convention, but scholars typically use "nationalist" to identify those delegates who recommended replacing the Confederation and the Congress with a more integrated union under a new and stronger central government (e.g., Rossiter 1966; Beeman 2009). What then to call their confederation-supporting opponents? "Localist" does not specify the locale (e.g., state, county, town), and "small-state localist" is not always correct (e.g., New York); it also is cumbersome, as is "states' rights advocate." "Federalist" is ineligible since it came to designate the nationalists in the Ratification period, and "Anti-Federalist," before then, was not much used. Since no good word currently exists but plainly is needed, I coin the term "confederalist." It better captures, I believe, the position of adherents to "the present Confederacy" (John Lansing on June 20) and is less prejudicial than any locution containing the prefix "anti," as in "anti-Virginia Plan forces" (Beeman 2009, 172). The application of "nationalist" and "confederalist" to particular delegates does not mean that those delegates conformed on every issue or that they remained true throughout the course of the Convention.

2. That subject has been treated by me before (Coby 2016). See also Slonin (2000) and Robertson (2005b). Other scholars who address the subject of proportional representation (and the Convention debates more generally) often employ the conceptual framing of principle vs. interest and conflict vs. consensus. Some of the former is in use here. Prominent contributors include Roche (1961), Wolfe (1977), Storing (1983), Jillson and Eubanks (1984), Banning (1987b), Nelson (1987), Rakove (1987), Zagarri (1987, 61-81), Onuf (1989, 360-64), Wirls (2003), Robertson (2005a), and Klarman (2016, 182-205). Nearest to this article is Wirls, for whom "Madison's Dilemma" refers to the mostly practical difficulties of combining proportional representation with other desired features of an upper house $(2003,158)$. This article's focus is more on the theoretical difficulties. 
the coming years would put them in the company of the three most populous states-Massachusetts, Pennsylvania, and Virginia. At the Convention they would vote their futures, Madison predicted, and join with northern states to form a voting bloc sufficient to carry the issue. "I am ready to believe that such a change would not be attended with much difficulty," wrote Madison to Washington (383).

Madison was wrong; no issue was more fiercely contested than proportional representation, which in the end the Convention rejected (July 16), if only for the upper house. What then happened to cause Madison to lose on an issue about which he had expressed such confidence and which occupied so prominent a place in his political thinking and in that of his fellow nationalists? Was defeat simply a matter of failure of nerve on the nationalists' part, ${ }^{3}$ or was there some deficiency in the argument that contributed to the coalition's undoing?

As just suggested, Madison was not alone in this fight. He received dogged and able support from James Wilson of Pennsylvania, Rufus King of Massachusetts, and George Mason of Virginia. Occasional, but generally reliable, support was also provided by Elbridge Gerry and Nathaniel Gorham of Massachusetts, Alexander Hamilton of New York, Benjamin Franklin and Gouverneur Morris of Pennsylvania, Edmund Randolph of Virginia, Hugh Williamson of North Carolina, and John Rutledge and Charles Pinckney of South Carolina. ${ }^{4}$ Many other delegates voted for proportional representation even if they did not speak up on its behalf.

\section{THE NATIONALIST CASE: PRINCIPLE}

The starting point and bedrock first principle for these large-state nationalists was the evident justice of equal voting by equal persons. Wilson deduced the principle from the sovereignty of the people, from which all political authority derived. "The Doctrine of Representation," he instructed, "is this-first the representative ought to speak the Language of his Constituents, and secondly that his language or vote should have the same influence as though the Constituents gave it-apply this principle and it concludes in favor of an equality

3. Most scholars think so, including Dahl, who calls the defeat of the nationalists "nothing more than the practical outcome of a hard bargain" $(2003,15)$. Klarman attributes their defeat to small-state inflexibility and equal state voting at the Convention $(2016,201)$. Beeman judges the debate over representation in the legislature to have been "for the most part, intellectually barren" $(2009,219)$. This article takes the contrary view, that the representation debate was among the richest of the whole Convention.

4. It might strike some readers as peculiar that the three nonsignatories to the Constitution-Mason, Randolph, and Gerry-are here regarded as nationalists, but on the question of proportional representation, they were nearly as hard-line as Madison, Wilson, King, Hamilton, and Morris. And, of course, the three were all from large states. 
of Representation \& against the present System" (June 9, Farrand 1966-87, $1: 179,185) .5$ Hamilton said of equal state voting that "it shocks too much the ideas of Justice, and every human feeling” (June 18, 1:286); Madison called it "confessedly unjust" (June 29, 1:464). He caught William Paterson, confederalist delegate from New Jersey, contradicting himself when Paterson claimed that slaves could not be counted in the represented population because slaves did not vote at home. "What is the true principle of Representation?" asked Paterson, about to sound like Wilson. "It is an expedient by which an assembly of certain individuals chosen by the people is substituted in place of the inconvenient meeting of the people themselves." Madison at once pounced, noting that by Paterson's "doctrine of Representation which was in its principle the genuine one," states "ought to vote in the same proportion in which their citizens would do, if the people of all the States were collectively met" (July 9, 1:56162; July 14, 2:8).

Determined to add a note of urgency to the debate, these nationalists insisted that unless government incorporated true principles of justice at the moment of its founding, certain and early demise would be its fate. "Bad principles in a Government though slow are sure in their operation and will gradually destroy it," warned Hamilton (June 18, Farrand 1966-87, 1:286-87). A government founded on the "vicious principle" of equal representation, said King, "must be as shortlived as it would be unjust" (June 30, 1:490). "A vice in the Representation, like an error in the first concoction, must be followed by disease, convulsions, and finally death itself," predicted Wilson (July 14, 2:10; also June 30, 1:483). Randolph, citing Montesquieu, proclaimed that "if a fair representation of the people be not secured, the injustice of the Government will shake it to its foundations" (July 11, 1:580). And Madison cautioned that an unjust principle "if admitted must infuse mortality into a Constitution which we wished to last forever" (June 29, 1:464). Madison reminded the Convention "of the consequences of laying the existing confederation on improper principles. All the principal parties to its compilation, joined immediately in mutilating and fettering the Government in such a manner that it has disappointed every hope placed on it" (July 14, 2:8). Governments formed badly at the start fail over time be-

5. Quotations from the Convention debates are from Farrand (1966-87). The first two of Farrand's four volumes contain the notes taken by Convention delegates, excluding those taken by John Lansing (in vol. 4, though actually an unnumbered supplement). The third volume contains Convention-related materials arranged in appendices. References to appendix A, the bulk of vol. 3, show the volume number, item number, and page number (e.g., Farrand 1966-87, 3, \#358, 475). Other appendices have no item numbers, and references give the appendix letter instead (e.g., Farrand 1966-87, 3, appendix B, 559). Misspellings of proper names are corrected; otherwise, original spellings are retained. Full words usually replace abbreviations. 
cause they are not trusted with—and so are not given—-the powers needed for success. $^{6}$

With the equality principle established-or at least repeatedly asserted, its importance underscored - the nationalists constructed their argument for proportionality upon three mutually supporting premises:

1. Parties subject to law must be coercible by law. Law compels compliance, and unless compliance is the result, law is merely advice. But if states are the subject parties, compliance would likely require war, and war is not law. "Such a government was necessary as could directly operate on individuals," explained Mason on May 30 (Farrand 1966-87, 1:34). On May 31 Madison expanded on the point: "The use of force against a State, would look more like a declaration of war, than an infliction of punishment, and would probably be considered by the party attacked as a dissolution of all previous compacts by which it might be bound" (1:54; also June 18, 1:285; and Federalist 15$)$. The problem with the Confederation was that its subject parties were states, and the problem with the Confederation Congress was that it had no clear legal authority to coerce the states-supposing that coercion were ever feasible-for the Congress, as the central government of a confederal union (con fideswith faith), trusted in the good-faith cooperation of its members (Rakove 1979, 173; 1996, 167; Beer 1993, 245-49). The Virginia Plan, presented to the Convention on May 29, attempted to correct this deficiency by empowering the national legislature "to call forth the force of the Union against any member of the Union failing to fulfill its duty under the articles thereof" (Resolution 6). The very next day Mason corrected the correction-law operating on individuals, not on states.

2. Parties subject to law (individuals, for being coercible) must have a say in the making of law. This principle traced to the Revolution ("No Taxation without Representation") and to the Declaration of Independence (consent of the governed). King asked, "And is it not a clear principle that in a free Government those who are to be the objects of a Government ought to influence the operations of it?" (July 14, Farrand 1966-87, 2:6). As the national government would reach individuals with its laws, so indi-

6. The confederalist response to this good-beginnings argument was that mistakes made at the start could be corrected in the future, drawing on experience as a guide (e.g., Oliver Ellsworth, June 29, Farrand 1966-87, 1:469; Gunning Bedford, July 5, 1:532). The nationalist counterresponse was that miracles do not repeat themselves (the Convention itself being judged a miracle) and that the country would not likely get another chance to write a sound constitution (e.g., Hamilton, June 29, 1:467; Madison, June 29, 1:476, 478; Randolph, June 16, $1: 256)$. 
viduals should reach the national government with their suffrages (Banning 1995, 142). Mason offered a useful comparison: "Under the existing Confederacy, Congress represent the States not the people of the States: their acts operate on the States, not on the individuals. The case will be changed in the new plan of Government. The people will be represented; they ought therefore to choose the Representatives" (June 6, 1:133). Practicality also supported these precepts of justice, since a people proportionately represented would have more confidence in their government and be more disposed to obey its commands (June 16, 1:256; Kramer 1999, 620-21).

3. Equal persons collected into unequal voting districts have voting rights proportionate to their numbers. This was the equality principle adjusted to the contingent fact of unequal states. Proportional representation of numbers respected the essential equality of each person, whereas equal representation of unequal states conferred more power on some persons than on others. If Virginia had 16 times the population of Delaware, and if every Virginian were the equal of every Delawarean, then Virginians collectively should have 16 times the vote. Wilson, the Convention's most consistent majoritarian and most persistent advocate for popular elections, asked rhetorically, "Are not the Citizens of Pennsylvania equal to those of N. Jersey? Does it require 150 of the former to balance 50 of the latter?" (June 9, Farrand 1966-87, 1:180). Eleven years earlier, at the Continental Congress, he pressed the same point, though in a tone decidedly sarcastic: "It is strange that annexing the name 'State' to ten thousand men, should give them an equal right with forty thousand. This must be the effect of magic, not of reason."7

In sum, proportional representation of persons was a requirement of justice because (1) the national government, unable to rule over states, would instead rule over individuals; (2) equal individuals had the consequent right to control by their suffrages the lawmaking of the national government; and (3) such individuals had that right in the same proportions to which they found themselves subjected to government's laws-that is, the subjection of 40,000 warrants four times the voting power as the subjection of 10,000 .

\section{THE NATIONALIST CASE: INTEREST}

Nationalist pleading consisted of more than just abstract principle. It included as well an accusation of wrongdoing, softened somewhat by intimations of

7. Recorded by Thomas Jefferson in his Notes of Proceedings in the Continental Congress (Jefferson 1950, 327). 
common purpose. The reason why proportional representation was not adopted at the first forming of the Confederation, said a trio of nationalists, was that the small states used the emergency of war to extort equal representation as the price of their cooperation. ${ }^{8}$ With characteristic bluntness Gouverneur Morris declared, "The small States aware of the necessity of preventing anarchy, and taking advantage of the moment, extorted from the large ones an equality of votes" (July 7, Farrand 1966-87, 1:552). Elbridge Gerry confessed that as a delegate to Congress he had surrendered "against his Judgment, and under pressure of public danger, and the obstinacy of the lesser States" (June 29, 1:467). Wilson used figurative language to deliver his indictment, likening large-state acquiescence to King Solomon's famous judgment in a maternity case, as well as to the natural mother in that case, who chose to lose her child to a false claimant rather than have it divided in two (June 20, 1:348; also June 9, 1:179). Taking a more conciliatory line, Madison explained that the injustice of equal state voting was tolerable under the confederal union because the states, functioning as instruments of federal law, could exert influence relative to their size, but that under the national union, where "the acts of the General Government would take effect without the intervention of the State legislatures," proportionality must show at the point of lawmaking, for otherwise "a vote from a small State would have the same efficacy and importance as a vote from a large one" (May 30, 1:37; also July 14, 2:9). Since factors that once palliated the injustice of equal suffrage would operate no longer, a change in representation was now required.

Even more conciliatory was Madison on June 28 when he held out the possibility of a reconfiguration of the states tending toward their equalization (Farrand 1966-87, 1:449). Some small-state delegates had earlier suggested that proportionality might be acceptable if state lines were first redrawn to produce 13 equal states. David Brearley of New Jersey carried the suggestion to its dramatic conclusion, proposing that "a map of the U.S. be spread out, that all the

8. The first vote for equal representation came on September 6, 1774. The counterproposal for proportional representation foundered, as Rakove explains, for the simple reason that the delegates to the First Continental Congress arrived in numbers unreflective of the size of the colonies represented (four from the second-largest colony, Massachusetts, but three from the smallest colony, Delaware), and because the Congress was without the means of ascertaining the populations of the colonies and their relative importance; moreover, the hope then was that decisions would be reached through consensus, making the exact apportionment of delegates a thing of little moment (1979, 140-41). After fighting had begun and the requisition of troops and money fell unequally on the colonies/states, the issue of proportional representation arose again. Various plans for union were circulated, culminating in the amended, John Dickinson draft of the Articles of Confederation. It was here that small-state intransigence was first encountered (July-August 1776). John Witherspoon of New Jersey provided a striking example, predicting that small states, if denied an equal vote, would become vassals of the large states, suffering a subservience like that of the Helots of Sparta and the provinces of Rome (Jefferson 1950, 324). 
existing boundaries be erased, and that a new partition of the whole be made into 13 equal parts" (June 9,1:177). Madison explained the practical difficulties involved but offered as a compromise the voluntary conjoining of small states with their larger neighbors (June 19, 1:321).

Behind Madison's conciliation lay the belief that an effective national government-the desideratum of nationalists more so even than proportional representation (Klarman 2016, 131, 182)—was imperiled by the existence of oversized states. Research on ancient and modern confederacies conducted by Madison in the spring of 1786 convinced him that confederations were discomposed by unequal parts attacking each other and attacking the center. In the Amphictyonic Confederacy, for example, "the Deputies of the strongest Cities awed and corrupted those of the weaker"; the Achaean Confederacy suffered from "the defect of subjection in the members to the general authority"; the Belgic Confederacy, strong in theory, was in practice weakened by "the Jealousy in each province of its Sovereignty"; and the Germanic Confederacy had its quotas "supplied very irregularly and defectively" because it proved "a delicate matter to execute [them] against the powerful members" (Madison 1975, 6, 8, 16, 22). A revolt of the states was the real danger, and the larger the state, the greater its ability to defy the central authority. Morris imagined a circumstance in which Massachusetts or Virginia, outvoted in the national legislature, would retaliate by ignoring its laws (July 5, Farrand 1966-87, 1:530). Nathaniel Gorham recognized the connection between the effectiveness of the national government and the diminishment of the states: "He hoped to see all the States made small by proper divisions. ... He conceived that let the General Government be modified as it might, there would be a constant tendency in the State Governments to encroach upon it; it was of importance therefore that the extent of the States should be reduced as much \& as fast as possible" (July 6, 1:540). ${ }^{9}$ Here then was a place where large and small states could come together, each achieving their separate end by one and the same means - protection of the national government and protection of the small states by reductions in the size of the large states, or adjustments in the size of all. Once achieved, voting methods in the legislature would make no difference, because proportional voting and equal voting among states that were equal in size would amount to the same thing. But getting there would take some time, and it mattered who in the interim would be called upon to exercise patience and trust. Small-state delegates wanted the burden borne by large states. And in response to assurances that state interest was unaffected by size, small-state delegates astutely observed that no danger could then arise from equal voting by states (June 20, 1:337).

9. See also Wilson on June 6 (Farrand 1966-87, 1:137), Hamilton on June 18 (1:285-86), Madison on June 19 (1:317), Morris on July 7 (1:552-53), and Gorham on July 23 (2:94). 


\section{TACTICAL ERRORS}

Small-state delegates had a case of their own to make, including a version of the majoritarian argument: to wit, three large states ought not to lord it over 10 small states (June 19, Farrand 1966-87, 1:324). From the nationalists' perspective, however, the small states were actuated by a desire to defend privileges long enjoyed (e.g., June 29, 1:466). Their intransigence, therefore, was rooted in self-interest (June 30, 1:491), perhaps wrongly understood (e.g., July 14, 2:8), but nevertheless deaf to arguments about justice (Rakove 1987, 443-44; $1996,66,76)$. From this point of view, the answer to the article's question is simple and straightforward: the nationalists lost the representation contest because the confederalists refused to budge, because without a compromise the Convention would fail, and because a failed Convention might precipitate a collapse of the Union. ${ }^{10}$

One by one did nationalists peel away, and quite literally in the cases of William Few (Georgia), William Pierce (Georgia), and William Blount (North Carolina). Being delegates to Congress as well as to the Convention, they left on Sunday, July 1, to attend to congressional business in New York. Monday, July 2, was the date of a critical vote, and the Georgia delegation without Few and Pierce was represented by William Houstoun and Abraham Baldwin. A nationalist stalwart heretofore, Baldwin voted aye on equal representation in the upper house, despite having spoken against it on June 29, splitting the rump Georgia delegation and causing it to vote divided. Meanwhile, Daniel of St. Thomas Jenifer, delegate from Maryland and sometimes check on the inveterate states' righter Luther Martin, arrived suspiciously late for the vote, allowing Martin on his own to vote aye for Maryland (Farrand 1966-87, 3, \#158, 188). ${ }^{11}$ Back on June 19 when the Committee of the Whole approved proportional representation in the upper house as part of the revised Virginia Plan, Maryland voted divided-Jenifer canceling out Martin. ${ }^{12}$ North Carolina stayed in the nay column, voting against equal representation, but its coming switch would be signaled on July 14.

10. A number of delegates were of the opinion that with the calling of the Convention no return to the Confederation and the Congress was any longer possible: Mason (June 4, Farrand 1966-87, 1:101), Randolph (June 16, 1:256), Gerry (June 29, 1:467; July 2, 1:515), and Pinckney (July 2, 1:511).

11. State legislatures determined the quorum number for their Convention delegations. Six legislatures required half or more to be present, while six others allowed less than half, and two, Connecticut and Maryland, permitted voting when only one delegate was present (Farrand 1966-87, 3, appendix B, 559-86; also 3, \#33, 33).

12. On June 11 the Convention voted 6-5 to adopt "some equitable ratio of representation"-i.e., proportionality — for the upper house. Maryland voted no, having previously voted divided on the same wording for the lower house, which meant that Jenifer first opposed Martin and then joined Martin. Maryland's other three delegates were not in attendance. 
Equal representation was in fact defeated on July 2, but only on a tie vote of 5-5-1. A committee was formed, charged with devising a compromise, and Gerry was its chair. Gerry reported for the committee on July 5. The plan recommended proportional representation for the lower house and equal representation for the upper house, with several subprovisions included. Nationalist disappointment was registered by Williamson, who "thought the propositions contained in it, the most objectionable of any he had yet heard" (July 5, Farrand 1966-87, 1:532). Gerry confessed his discomfort but also his assent, saying that as America was "neither the same Nation nor different Nations ... we ought not therefore to pursue the one or the other of these ideas too closely," and he prophesized secession if some accommodation were not reached (July 5, 1:532). His defection was followed by that of fellow Massachusetts delegate Caleb Strong, who announced on July 14 his intention to vote for the committee's proposal. When the decisive vote came, on July 16, Massachusetts-with Gerry and Strong having given up the fight, but with King and Gorham still holding firm — voted divided, Maryland voted aye, North Carolina moved to aye, but Georgia switched back from divided to nay. The New York delegation had left the Convention, taking with it its one aye vote. Nevertheless, the final tally was 5-4-1 in favor of equal representation: Connecticut, New Jersey, Delaware, Maryland, and North Carolina aye; Pennsylvania, Virginia, South Carolina, and Georgia nay; Massachusetts divided (Wirls 2003, 176-80; Robertson 2005a, 138-47).

The following morning (July 17), before the Convention began its session, a number of large-state delegates gathered in the State House to conduct a postmortem and devise a way forward, but "the time was wasted in vague conversation on the subject, without any specific proposition or agreement," wrote Madison (Farrand 1966-87, 2:19-20). Large-state delegates could not concur on the seriousness of the concession or on the wisdom of presenting a separate plan of their own. And they had to suppose that the missing states (New York, New Hampshire, and Rhode Island) would side with the opposition (July 16, 2:18; see also Rossiter 1966, 189; Banning 1987a, 123; Beeman 2009, 222). So they capitulated, and the small-state delegates in attendance concluded "that they had nothing to apprehend from a union of the larger, in any plan whatever against the equality of votes in the $2^{\text {nd }}$ branch" (Farrand 1966-87, 2:20).

Simple and straightforward though it may be, this narrative of events does not fully account for why nationalists rather than confederalists were the ones to lose heart and yield. Wilson arrived at the Convention expecting only a partial union to be its result, but "with a door open for the acession of the rest" (June 5, Farrand 1966-87, 1:123). Take what could be achieved now, he reasoned, whether a majority or a minority of the states (June 9, 1:179), and wait 
for the remainder to see the light and join at their pleasure. And as the Convention wore on, other nationalists expressed an openness to partial unions, including Morris on the third day. ${ }^{13}$ Additionally, the nationalists perceived clearly that the small states had more to lose in the event of failure and could less afford to stand by the ultimatums they so regularly issued. Large states would be more menacing to the small ones outside of union or in separate confederations, Madison warned (June 19, 1:320; June 28, 1:448), and Gorham "conceived that a rupture of the Union would be an event unhappy for all, but surely the large States would be least unable to take care of themselves, and to make connections with one another" (June 29, 1:462).

Why then did it happen that when a grand committee was approved, on July 2, its elected members consisted solely of accommodationists from the nationalist camp and of hard-liners from the confederalist? ${ }^{14}$ This committee's election proved to be the turning point of the Convention. Mason, a committee member, speculated that "accommodation was the object of the House [Convention] in the appointment of the Committee." Mason had become an accommodationist himself because "he would bury his bones in the City rather than expose his Country to the Consequences of a dissolution of the Convention without any thing being done" (July 5, Farrand 1966-87, 1:533).

A strong majority wanted the Convention to continue, and it was obvious enough that some accommodation would be required to keep the Convention from breaking apart. But why this particular accommodation, which for the nationalists surrendered the principle at stake? Other compromises were available, less damaging to the nationalist position. For instance, Roger Sherman, a Connecticut confederalist and the delegate usually credited with authoring the Great Compromise, moved in committee "that each State should have an equal vote in the $2^{\text {nd }}$ branch; provided that no decision therein should prevail unless the majority of States concurring should also comprize a majority of the inhabitants of the U. States" (July 5, Farrand 1966-87, 1:526). According to Madison's note, this proposal for "double-majority" voting gained little traction in committee. But it was appealing nonetheless and worth bringing before the whole Convention, for it treated individual states equally, while treating combinations of states proportionally. ${ }^{15}$ It also had a substantial pedigree, reaching

13. See Morris on May 30 (Farrand 1966-87, 1:37), Gorham on June 29 (1:462), Wilson and King on June 30 (1:482, 489), Madison on July 5 (1:529), and Gerry on July 6 (1:541). See also Onuf (1988, 43-45).

14. Gerry, Franklin, Mason, Rutledge, and Baldwin were the nationalists elected, while Ellsworth (but with Sherman substituting), Robert Yates, Paterson, Bedford, Martin, and William Davie were the confederalists elected. A committee with one member from each of the delegations was commonly referred to as a grand committee.

15. While on one level the proposal was symbolic, affording the appearance of equality but not the reality, on another level it offered small states a significant prize, since each would 
back to the early days of the Continental Congress. ${ }^{16}$ Madison would himself propose it when the subject was ratification (August 31, 2:475), but here he was silent, and the double-majority alternative fell away.

A second neglected idea of considerable merit was that put forward by Charles Pinckney. Pinckney proposed, four (or five) times, a voting scheme loosely proportional, in which states would be sorted into three or five categories according to size. ${ }^{17}$ Some account would thus be taken of the vast disparity in population separating Virginia and Delaware, but the differential would stop well short of the 16-1 that strict proportionality required. With the exception of Rutledge, a fellow South Carolinian, Pinckney received no support from the nationalists until July 14, when the proposal was last made. Wilson seconded, and Madison called it "a reasonable compromise." Gerry liked it too, but he thought that its time had passed and that an accommodation "on the ground of the motion" could not succeed (July 14, Farrand 1966-87, 2:6). When Madison next took the floor, he did not speak up for the Pinckney proposal; ${ }^{18}$ rather, he returned to a proposal made previously by Franklin on June 30, one that would have the upper house voting equally or proportionally depending on the nature of the issue. Madison had no confidence that such a discrimination could be made, and he concluded by denying that any true ground of compromise existed, even though he had just heard his ally Gerry assert that "an accommodation must take place" (2:5). The July 14 vote on the Pinckney proposal was 6-4 against. Maryland was in favor (likely because of the arrival of Daniel Carroll), but North Carolina and Georgia voted no. ${ }^{19}$

A tactical mistake was thus one reason why the nationalists failed in their objective. At the point when some among them began expressing doubts (e.g.,

have the same number of senators in the chamber as any large state, and since the debating and bargaining skills of those present would to some degree affect the votes cast. The proposal also had the advantage of ease of operation, requiring only a check to confirm that the lowerhouse delegations of the states composing an upper-house majority represented a majority of the lower house too.

16. The Connecticut plan of confederation, published in March 1776, proposed that "the concurrence of a majority of the Colonies represented, and also a majority of the Delegates present, shall be necessary to make a vote of the Congress" (Rakove 1979, 145-46, 158-59).

17. Pinckney offered his proposal on June 7 (Farrand 1966-87, 1:155), June 8 (1:169), July 2 (1:511), and July 14 (2:5). Brief mention of the proposal appears in Lansing on June 25: "States ought to be divided into five Classes-to have from one to five Votes" (4:112).

18. Madison's tardiness and reserve are hard to explain, since the Pinckney proposal approximated the practice of the Lycian Confederacy, recommended by Montesquieu (Spirit of the Laws, 9.3) and by Madison citing Montesquieu (Farrand 1966-87, June 30, 1:485). See also Federalist 9 . Concern that large states would reject a constitution that diminished their influence relative to small states is how Kramer explains Madison's reluctance to compromise (1999, 655); see also Jillson $(1988,47)$.

19. For speculation on the behavior of the North Carolina delegation, see Wirls (2003, 178-79). 
Mason's insistence that state governments be accorded the means of selfdefense; June 25, Farrand 1966-87, 1:407), it was incumbent on the hardliners to investigate the compromises and rally around the best on offer. ${ }^{20}$ But they ignored evidence of defections and clung fast to the goal of full proportionality throughout the legislature, losing in the event the chance at partial proportionality in the upper house (Collier and Collier 1986, 177).

\section{THEORETICAL ERRORS}

The more serious reason, however, had to do with deficiencies in the argument itself. The nationalists took their stand on the ground of human equality. Equal people must be equally represented; departures from the principle are unjust and destabilizing. But nationalists were not themselves thoroughgoing egalitarians. Even Wilson, who insisted on deferring to the good judgment of the people, did so in confidence that the people would be willing to defer to the still-better judgment of Wilson (August 14, Farrand 1966-87, 2:287-88). In applying the equality principle to the upper house, nationalists ran into this difficulty: that the Senate-called that with the report of the Committee of Detail-was, like the Roman senate, intended to be the chamber where wisdom and virtue resided (June 26, 1:423). The Senate would be invested with special powers, reserved appropriately for the wise and the virtuous (June 25, 1:406; June 26, 1:426), and would serve as a check on the folly and injustice of the lower house (June 12, 1:218), now called the House of Representatives. Why then was it important that the Senate be organized like the House? In other respects-mode of election, size of chamber, term of office, staggered terms, age, residency-it was not. So why in the matter of representation (Rakove 1996, 78-79; Wirls 2003, 160-61)? More to the point, how would the equal representation of states, as opposed to their proportional representation, result in the election of senators less wise and virtuous? Absent a convincing answer to this question, confederalists had cause to conclude that large-state nationalists were promoting their own large-state interests, not striving to construct good government for all (June 30, 1:491).

In fact, something quite the opposite of a convincing answer was supplied when the discussion turned to mode of election. Wilson wanted both houses of the national legislature "to flow from the people at large." But appreciative of

20. Besides plans by Sherman, Pinckney, and Franklin, Wilson suggested a scheme of attenuated proportionality whereby the allotment of one senator per 100,000 persons would be suspended for small states until their populations reached the 100,000 threshold (June 30, Farrand 1966-87, 1:488). King proposed a bill of rights for states (June 30,1:493), and, in seeming desperation, he later proposed a three-chambered legislature, with the third chamber designated the representative body of the states (July 14, 2:6-7). 
the aristocratic purposes assigned to the upper house, he proposed popular election in large electoral districts, expecting that "men of intelligence and uprightness" would be elected thereby. Most nationalists, however, preferred an alternate means of accomplishing that goal, and on June 7 the Convention, with their support, voted unanimously for election by state legislatures. ${ }^{21} \mathrm{John}$ Dickinson of Delaware, a moderate nationalist, best expressed the Convention's thinking: "he wished the Senate to consist of the most distinguished characters ... and he thought such characters more likely to be selected by the State Legislatures than in any other mode." Madison recognized the effect this electoral mode would have on proportionality—namely, "a surrender of the principle," as he stated in a note (June 7, Farrand 1966-87, 1:151-54). Proportionality, he feared, could not survive election by state legislatures, since the Senate would be too large if the most populous state's suffrage were proportionate to the smallest state's, which was one. ${ }^{22}$ Thus, in choosing this mode of electionand this mode of electing the wise and the virtuous-large-state nationalists contributed to the defeat of their own principle. When the Convention, on June 25, reaffirmed its decision of June 7, Madison repeated his charge that the nationalists were beating themselves by siding with small-state delegates opposed to proportional representation (1:408).

The nationalists were aristocrats (or "natural aristocrats," the term in use at the time) perhaps as much as they were democrats. ${ }^{23}$ Their aristocratic nature showed in the debate on eligibility for offices. ${ }^{24}$ It also showed in some early remarks on the composition of the Senate. For in the minds of some delegates, the upper house was to be a deliberative rather than a representative body, com-

21. On May 31, by a vote of 7-3, the Convention rejected the Virginia Plan's proposal for election of senators by the lower house of the national legislature, but without yet supplying a replacement mode.

22. This particular problem admitted an easy solution, which surprisingly no one thought to propose-namely, weighted voting. Virginia could realize its 16-1 advantage over Delaware with four senators casting four votes each against Delaware's one senator casting one vote; meanwhile, the Senate would be left small enough to perform its aristocratic function.

23. Democracy means direct rule by the people assembled; any departures therefrom, beginning with representation, make the system of government less democratic-a point trenchantly developed by Morris in "Of Political Liberty," one of the short essays contained in his Political Enquires (Morris 2012, 7-8). No one at the Convention quarreled with representation, and few objected to bicameralism (June 20, Farrand 1966-87, 1:339). The literature on the democratic vs. aristocratic/oligarchic character of the Constitution is long-standing and extensive. See, e.g., Beard (1913), Diamond (1959), Smith (1965), Eidelberg (1968), Wood (1969), Goldwin and Schambra (1980), Dahl (2003), and Amar (2005). Hutson (1987) provides an overview.

24. See the debates of June 12, June 22-23, June 26, August 14, September 3, and September 14 . The eligibility debate pitted delegates eager to recruit talented persons into government service against delegates determined to close all doors to political corruption. For a discussion of Madison's view on this issue, see Gibson (2012, 192-93). 
posed of "natural aristocrats" drawn from around the country without responsibility for particular localities, thus effectively divorced from the states. ${ }^{25}$ Franklin confided that he "was originally of opinion it would be better if every member of Congress, or our national Council, were to consider himself rather as a representative of the whole, than as an Agent for a particular State" (June 11, Farrand 1966-87, 1:197). Morris did as bidden, describing himself as “a Representative of America ... and of the whole human race” (July 5, 1:529)!

A core nationalist argument-premise 2-stipulated that persons subject to law have a corresponding right to participate in the making of law. Apart from the presence of subject persons with no voting rights at all, a glaring inconsistency, this argument sat uneasily with the nationalists' meritocratic aspirations and commitments. ${ }^{26}$ For it focused exclusively on the passivity of people, on their being affected by, or suffering, law, not on the activity of people, on their contributions to political order and their capacity for self-rule. As such, it reflected a democratic, not an aristocratic, understanding of distributive justice. ${ }^{27}$ Morris articulated the aristocratic understanding when debating freehold suffrage: "Children do not vote. Why? Because they want prudence, because they have no will of their own. The ignorant and the dependent can be as little trusted with the public interest" (August 7, Farrand 1966-87, 2:203). Only those who

25. Worry about the size of the upper house if proportionality were employed caused Wilson to suggest the conjoining of election districts. Madison, though opposed, carried the idea to the conjoining of states (May 31, Farrand 1966-87, 1:52; also June 7, 1:153). George Read of Delaware proposed appointment of senators by the executive from nominees provided by the state legislatures, but without any requirement of state representation (June 7, 1:151). Hamilton recommended lifetime appointment of senators in order to provide a "permanent will, a weighty interest" to the government, a term of office that effectively would sever all ties to the states (June 18, 1:290). Pinckney's plan of government, presented to the Convention on May 29 and then referred to the Committee of Detail on July 24, contained in Article 4 the following description of the Senate: "Senate to be elected from four Districts" (July 26, 2:135). See Wirls (2003, 164-67), who tabulates all delegate remarks on the characteristics of an upper house.

26. Slaves, of course, would be included here, but also women, children, and propertyless men. See the famous letter of Abigail Adams to her husband John ("Remember the Ladies") and his equally famous reply ("the Despotism of the Petticoat") of April 1776 (Adams 1975, 120-21, 121-23); see also the letter of John Adams to James Sullivan of May 26, 1776 (Adams 1977, 4:208-12).

27. Aristotle, Politics, 3.5.1-5; 3.9; 4.4.22-23; 5.1.2-4, 12-15; 6.2.1-4, 9; 7.8.1. When discussing distributive justice, Aristotle does not quite say that people share in rule because they suffer the effects of rule. What he rather says is that democrats are wont to base their claim to rule on equal freedom and on greater numbers, whereas aristocrats and oligarchs base their claim on contributions and capacity. The first claim Aristotle calls numerical equality, the second proportional equality. Aristotle's general purpose in the Politics is to persuade democrats that they can compete on grounds of contribution/capacity/merit and so should forego numerical-equality claims in favor of proportional-equality claims, the superior justice of which, he maintains, all classes acknowledge, or can be brought to acknowledge (3.9.1-4, 3.17.6, 5.1.13). 
are competent electors of the wise and the virtuous vote, not those whose primary qualification is that they are affected by law.

The problem then with the equality principle and with its law-subjection corollary was that they did not apply to an upper house conceived as a quasiaristocracy. Indeed, the nationalist argument better suited the confederalists, who often averred that states generally, and small states particularly, must have the constitutional means of defending themselves, just as do the branches of government under separation-of-powers theory (e.g., June 30, Farrand 1966-87, 1:484) — that is, passive suffering that warrants protection as the rationale, not active capacity that accomplishes good. ${ }^{28}$ Since the states were the subjects of law, they must have a voice in the formation of law.

But were they, going forward, to be the subjects of law? Premise 1 of the nationalist argument required that coercible parties be the subjects of coercive law, meaning that law should operate on individuals rather than on states. King avowed that the national government would in all cases act only upon individual citizens: "There never will be a case in which it will act as a federal Government on the States and not on the individual Citizens" (July 14, Farrand 1966$87,2: 6)$. Madison concurred, asking "for a single instance in which the General Government was not to operate on the people individually" (July 14, 2:9). The cocksure certitude exhibited by these two nationalists is a little hard to reckon, however, given that the Virginia Plan was silent on the subject. The document used the word "national" 18 times, and some delegates inferred from it a government whose power extended to individuals. ${ }^{29}$ But whether that power ex-

28. Wilson captured the activist aim of nationalist theory when he explained the cost of popular majorities in one chamber stymied by state majorities in the other: "Bad Governments are of two sorts. 1. that which does too little. 2. that which does too much: that which fails through weakness; and that which destroys through oppression. Under which of these evils do the U. States at present groan? Under the weakness and inefficiency of its Government" (June 30, Farrand 1966-87, 1:483-84; also July 14, 2:10). See Rakove (1987, 447-48).

29. Randolph, the plan's nominal author, understood "national" to mean legislation over individuals; this he called "real legislation" (June 16, Farrand 1966-87, 1:256). But it is curious-if indeed "national" were meant to carry the full weight of the idea of law operating on individuals - that when Ellsworth moved to have the word dropped from Resolution 1 of the revised Virginia Plan and replaced by "United States," the Convention agreed without opposition (June 20, 1:335-36; June 25, 1:404). Ellsworth had other reasons for recommending the change and Randolph other reasons for acceding to it (Jillson 1988, 84-85), suggesting that neither was then thinking of it in this way. The word crept back into debate (e.g., June 30, 1:497) and into the 23 resolutions referred to the Committee of Detail (July 26), but the committee's report (August 6) was careful to replace "national" with "United States," as Ellsworth had requested. Read attempted a similar substitution on May 30 ("more effective Government") but was rebuffed (1:35). Many years later, in a letter to Thomas Cooper (December 26, 1826), Madison treated the change as a simple clarification meant to guard against misrepresentation, but Luther Martin, shortly after the Convention, described it as a subterfuge meant to quiet alarm (Farrand 1966-87, 3, \#358, 475; \#158, 195). 
tended exclusively to individuals and whether a confederal government's power extended exclusively to states were points much debated and not well understood. ${ }^{30}$ One cause for doubt was Resolution 6 of the Virginia Plan, which granted to the national legislature the power "to negative all laws passed by the several States, contravening in the opinion of the National Legislature the articles of Union," and which empowered the government, as noted previously, "to call forth the force of the Union against any member of the Union failing its duty under the articles thereof" (May 29, 1:21). It is safe to say that the Virginia Plan in its first iteration did not reflect the nationalist principle that parties subject to law must be coercible by law and that law, therefore, must apply to coercible individuals and not to incoercible states. ${ }^{31}$ The latter provision about calling forth the force of the Union was removed from the revised Virginia Plan reported by the Committee of the Whole on June $13 .{ }^{32}$ But the negative survived until July $17 .{ }^{33}$ In debate, Madison offered it as a safer alternative to forcible intervention, contending that "should no such precaution be engrafted, the only remedy would lie in an appeal to coercion," but that "the negative would render the use of force unnecessary" (June 8, 1:164-65). The explanation for this peacemaking effect was that the national legislature, as envisioned by Madison,

30. Madison noted that in some confederations and in the New Jersey Plan the powers of the federal government sometimes operated on individuals (e.g., piracies), even though they were supposed to operate on states (June 19, Farrand 1966-87, 1:314; also June 28, 1:447). Paterson concurred regarding the New Jersey Plan (June 16, 1:251). Hamilton tried to minimize the importance of the distinction: "In some instances the powers are exercised over collective bodies; in others over individuals" (June 18, 1:283). In a post-Convention letter to Jefferson (October 24, 1787), Madison made law operating on individuals the central pillar of the new government and the rationale for proportional representation (Madison 1977, 207).

31. Resolution 2 of the Virginia Plan permitted use of "Quotas of contribution" for determining representation, which, if used, would likely subject states to a federal requisition. Resolution 9 empowered the national judiciary to adjudicate disputes respecting collection of the national revenue and the peace and harmony of the Union; such disputes would necessarily involve the states. Resolution 10 provided for the admission of new states arising from "a voluntary junction of Government \& Territory or otherwise." The phrasing is difficult, but in subsequent debate (August 29-30) "voluntary junction ... or otherwise" meant statehood for territories, with ("voluntary") or without ("otherwise") the approval of the states to which they were formerly joined. If the Virginia Plan was contemplating a national government authorized to force states to surrender control of their territories, then plainly this was a national government that in some respects was operating on states.

32. A version of the same power reemerged, however, with the report of the Committee of Detail (Art. 7.1), and a version of that power exists in the Constitution today (Art. I.8), namely, the power "to call forth the aid of the militia, in order to execute the laws of the Union, suppress insurrections, and repel invasions." The most likely target of this martial enforcement of national law would be the state governments.

33. A vestige of the negative appeared in the report of the Committee of Style and Arrangement, of which Madison was a member. Article 1.4 gave the legislature the power to alter state regulations respecting "the times, places and manner of holding elections." Here was an opportunity for the national government to review and overturn a state law. 
would function as a third chamber of each state legislature, stopping bills before they could go forward as laws_- "an essential branch of the State Legislatures," he called it (June 28, 1:447). He further likened the negative to the royal veto exercised by the British monarch over colonial legislation (July 17 2:28; see Zuckert 1987, 142; LaCroix 2010, 145-58). Rather than having one sovereign dictating policy to another sovereign and so raising the problem of imperium in imperio, one sovereign, as it were, was being absorbed into a second to serve as a check, with the two now reconstituted as one. The value of this depiction was that the decisions of the national legislature, issuing not from without the states but from within, could be represented as applying to individuals, commanding or forbidding them much as did state laws. But would metaphorical imaginings of this sort be enough to salvage the nationalist principle that law must operate on individuals only? For on the face of it, Madison's vaunted negative was indeed operating on states (Zuckert 1986, 183, 189, 197, 199; Banning 1995, 147, 154; Rakove 1996, 174)_for example, the Georgia state legislature passes a law abrogating a treaty obligation, and the national legislature steps in to nullify that law. In such a case, who would the coerced party be-individuals affected by the law, or the state legislature that had passed it? ${ }^{34}$

A second area of ambiguity was direct taxation. While the taxing power was always in the back of delegates' minds (June 29, Farrand 1966-87, 1:464), direct taxation came to the fore only on July 12 when offered by Morris as a counterweight to representation. ${ }^{35}$ A direct tax, all agreed, was some sort of population tax and/or wealth tax, which was to be paid in proportion to the state's representation in the Congress. But there agreement ended. For some of the delegates conceived of the tax as a requisition, or quota, levied by the federal government and paid by the state governments; others, however, thought of it as a

34. The actual operation of the negative was never settled in debate because of doubts about its practicality and utility (Klarman 2016, 154-58). Three understandings, however, did emerge: (1) prior national approval before a state law could go into effect, (2) national repeal sometime after a state law had gone into effect, and (3) state executives appointed by the national government and exercising a veto over state legislation (August 23, Farrand 1966-87, 2:391). Madison preferred the first understanding (July 17, 2:27), but in response to objections that the national legislature would not have the time or competence to review every law sent up from every state (roads and bridges, asked Mason; August 23, 2:390), he proposed confining the work to the Senate along with sanctioning "some emanation" of the national government to give a temporary effect to urgent legislation (June 8, 1:168; July 17, 2:28). He opposed the second understanding on grounds that too much damage could occur in the interim (July 17, $2: 27)$. Conceivably, his "some emanation" might take the form of nationally appointed governors, as recommended by Hamilton (June 18, 1:293) and Pinckney (August 23, 2:391), though in the March 19, 1787, letter to Jefferson, Madison described it as a "set of men" (Madison $1975,318)$. Rakove calls it a "federal proconsular authority" $(1987,432)$.

35 . King was actually the first to tie representation to taxation, though not to direct taxation (July 9, Farrand 1966-87, 1:562). 
capitation tax paid by individuals, perhaps in the form of a poll tax (July 12, 1:597; July 13, 1:603; see Maier 2010, 31; Klarman 2016, 275). Mason was of the former view, assuming that a tax pegged to representation would "drive the Legislature to the plan of Requisitions" (July 12, 1:592). Gerry too saw it as a requisition, which he initially rejected, since "the States were not to be taxed as States" (July 12, 1:597). He proposed instead assessing a direct tax "on the inhabitants of the several states" proportionate to a state's representation in the lower house (July 13, 1:600-601). When his motion failed, which included a plan for collecting tax revenues during the years preceding the first census, he changed the phrasing to "an assessment on the States" (July 13, 1:603). Meanwhile, Morris, the originator of the direct tax, understood it plainly as a capitation tax, for which reason he judged that it would prove impossible to collect: "It is idle to suppose that the General Government can stretch its hand directly into the pockets of the people scattered over so vast a Country" (August 8, 2:223), and "for a long time the people of America will not have money to pay direct taxes" (August 16, 2:307; July 17, 2:26). ${ }^{36}$ Was direct taxation then a requisition imposed on states, or was it a head tax imposed on individuals? King had the temerity to ask "what was the precise meaning of direct taxation" (August 20, 2:350). The response, recorded by Madison, was, "No one answered" (Rakove 1996, 179).

The uncertainty surrounding direct taxation, like that surrounding the negative, undermined Madison's assurance that in no "single instance" would the general government operate on the states. It just might; ${ }^{37}$ if it did, then the states, as states, were deserving of representation in accordance with the principle that those subject to law must have a say in the making of law proportionate to the extent of their subjection. And being equally subject, the states were

36. Why did Morris propose a tax he thought could not be collected? On July 24 he described the linkage of direct taxation to representation as a tactical maneuver, "a bridge to assist us over a certain gulph; having passed the gulph the bridge may be removed" (July 24, Farrand 1966-87, 2:106). It did not matter to Morris then that this tax was uncollectible, since its purpose-as explained by Madison in a note- "was to lessen the eagerness on one side, \& the opposition on the other, to the share of representation claimed by the Sothern States on account of the Negroes" (106).

37. The final draft of the Constitution contains numerous examples of national law operating on state governments-some 25 in Article I, sections 1 and 10, and Article IV, depending on how one counts (Wolfe 1977, 104-5). Two questions arise concerning intergovernmental relations in a compound republic. The first asks whether, practically speaking, one level of government can legislate for another without having to resort to war in order to enforce its commands. The answer might be, time will tell and habit can make up for the solecism of imperium in imperio (Beer 1993, 250-55). The second asks about the theoretical implications of legislating for states. The answer here is that equal representation of states is a necessary consequence of their equal subjection to law. 
entitled to an equal say. Put differently, the failure to deliver on premise 1 - that law apply only to individuals-warranted alterations to premises 2 and 3.

\section{DEFEAT}

Shortly before the final vote on representation, and in an apparent attempt to mollify the nationalists who were about to lose, Sherman suggested that the real contest was not between large and small states, but between the states themselves and the national government. All states, regardless of size, stood threatened by the national government and would be similarly benefited by the protection of an equal vote (July 14, Farrand 1966-87, 2:5).

Wilson responded to Sherman's overture, but probably not in the way that Sherman had expected. Yes, said Wilson, the states collectively shared a common relationship to the national government and had interests in common that needed defending. But the large states, he contended, could perform this work for the whole: "Is there any reason to suppose that if their preservation should depend more on the large than on the small States, the security of the States against the General Government would be diminished? Are the large States less attached to their existence, more likely to commit suicide, than the small?" (July 14, Farrand 1966-87, 2:10). Wilson's retort proved unfortunate for the nationalist cause, since it played into the confederalist suspicion that the large states were in fact more attached to their existence and that they would act on these attachments to the detriment of the small states. In light of the size and importance of Virginia, called the Old Dominion, it only made sense that state identity would resonate with its citizens more than it would with the citizens of Delaware, an appendage of Pennsylvania until the Revolution and called the Three Lower Counties (Roche 1961, 807; Zuckert 1986, 206-7; Murrin $1988,42)$. As it happened, several small-state delegates were willing to contemplate a union without the states, and they regularly employed conditional language when pushing their demand for equal state suffrage: "If the sovereignty of the States is to be maintained," said Paterson of New Jersey (June 16, 1:251); "in case the States, as was proposed, should retain some portion of sovereignty," said William Samuel Johnson of Connecticut (June 21, 1:355); "If the States remain," said George Read of Delaware (June 29, 1:463). Martin of Maryland asked, "Will the representatives of a state forget state interests? ... These prejudices cannot be eradicated-Your general government cannot be just or equal upon the Virginia plan, unless you abolish state interests" (June 28, 1:453).

This complaint caught the attention of nationalists, causing even the most resolute to reassess their position. Hamilton had to concede "that common residence within the same State would produce a certain degree of attachment; and that this principle might have a certain influence in public affairs" (June 29, 
Farrand 1966-87, 1:466; also June 18, 1:285). Pinckney granted that "the large States would feel a partiality for their own Citizens and give them a preference in appointments" (July 2, 1:510). Randolph admitted the possibility of a combination of large states (July 2, 1:514). And Gorham acknowledged "some weight in the objections of the small States"; for while three or four of them, with combined populations equaling Virginia's, would together cast the same number of votes, their delegations would find working in concert substantially more difficult than the one delegation of Virginia, to which a common identity and purpose had been imparted (June 25, 1:404-5; also June 27, 1:438; July 6, 1:542). Even Madison-who extrapolated proportional voting by states from proportional voting by counties (June 28, 1:447)—allowed that "local partiality" affected election results when large and small counties were united into one voting district (May 31, 1:52). The nationalists then faced this dilemma: either opt for eliminating the states, lest a parochial favoritism arising from state attachments influence national policy to the benefit of the large states and the harm of the small, or, in retaining the states, provide them with equal suffrage as the means of self-defense. According to Martin, justice required one or the other.

Among the nationalists Hamilton came nearest to saying that the states must go: "Two sovereigns cannot co-exist within the same limits"; but for public opinion, he added, "he saw no other necessity for declining" to recommend their extinction (June 18, Farrand 1966-87, 1:287). But decline he $\operatorname{did}^{38}$-as did Wilson, who "was tenacious of the idea of preserving" the states, despite denominating them "imaginary beings" and "metaphysical distinctions" (June 19, 1:322; June 30, 1:483). Small-state delegates tried calling out nationalists as pure consolidationists (e.g., June 2, 1:85; August 21, 2:362), and on two occasions Madison very nearly took the bait, claiming that "no fatal consequences could result" from the general government's absorbing the state governments (June 21, 1:357-58) and that "the true policy of small States . . . lies in promoting those principles \& that form of Government which will most approximate the States to the condition of counties" (June 28, 1:449). But neither he nor the nationalists were willing to go that far. ${ }^{39}$ And therein lay the problem.

38. In a September 16, 1803, letter to Timothy Pickering, Hamilton claimed that at the Convention he "never contemplated the abolition of the state Governments" (Farrand 1966-87, 3, \#295, 398).

39. Madison expressed support for the states on June 21 (Farrand 1966-87, 1:357) and June 30 (1:490). Other nationalists who ascribed an important, albeit subordinate, role to the states were King (June 30, 1:492), Pinckney (June 25, 1:404, 411-12), and Williamson (June 25, 1:407). Scholars who characterize the nationalist position-and Madison's nationalism — as a middle ground between confederation and consolidation are Wolfe (1977), Banning (1983; 1987b; 1995, 162-65, 170-72), Zuckert (1986), Kramer (1999), Hendrickson (2003, 5-6, 221), and Tate (2013). Scholars of the opposing view include Brant (1948, 301, 418), Diamond (1961), Roche (1961), Jensen (1964, 51), Yarborough (1987), Carey (1995), and Klarman (2016, 240-43). 
For the nationalists acceded to the states' continued existence, when what their position logically required was the removal of the states or their reduction to county-like status. ${ }^{40}$ As a principle, proportional representation is most compelling when applied to equal individuals who by happenstance find themselves collected into unequal voting districts. Owing to the accidents of history and geography, these districts vary in size and population, and proportional voting simply reflects their accidental inequality while upholding the essential equality of their inhabitants. But when districts are states and as states are appreciated as political societies in their own right (e.g., William Johnson, June 29, 1:461), they take on the attributes of individual persons for whom equal representation is appropriate. In the end, the case for proportional representation failed because the nationalists were not pure consolidationists, whereas their argument for the same required that they be. Hamilton was right, even if he wavered: the states, "as States . . . ought to be abolished" (June 19, 1:323).

The case also failed, as observed previously, because the aristocratic character of the upper house did not require use of proportional representation, a democratic practice. Only Wilson adhered consistently to the logic of proportionality, campaigning to democratize the national government by basing most of its offices on direct popular elections.

\section{CONCLUSION}

Madison thought that proportional representation would be an easy sell because the interests of a majority of the states supported it. Several of his fellow nationalists thought that the unprincipled manner in which equal representa-

40. Mary Sarah Bilder contends-in her study of Madison's Notes, based in part on the handwritten sheets housed in the Library of Congress-that Madison inserted replacements for two of the three late-June speeches on proportional representation (June 21 and 29, but not June 28). She then compares Madison's replacement version of the June 29 speech (the original does not exist) with the accounts of other notetakers active that day (her practice throughout). She observes that King and Paterson recorded Madison as calling states corporations and placing them on the low end of a continuum of sovereignty (King only). Madison for his partand in his replacement speech-avoided the word "corporation," and while he spoke of a continuum of sovereignty, he did not specify where on it the states fell. When discrepancies of this sort occur, Bilder generally supposes that the other notetakers have captured and preserved Madison's actual comments in the Convention, and so she reasons that Madison initially regarded the states as corporations, defined as "subordinate political authorities with delegated powers." She concludes that such an understanding "fit his theory of proportional representation in both houses. It made coherent his commitment to a national government that operated on individuals" (Bilder 2015, 100; also 245-46). This article argues the same, while further arguing that reluctance to embrace wholeheartedly and consistently the corporation analogy weakened the case for proportional representation. No judgment is intended respecting Bilder's larger claim that Madison was inserting pages and revising text in order to disguise strategic mistakes made at the Convention or better align the Notes with his later political positions (e.g., 115, 216). 
tion was forced on the Congress would cause embarrassment sufficient to prevent a repeat of that decision. Some nationalists thought themselves free of the obligation to compromise, because the most they expected of the Convention was a partial union of the willing. Still others thought that concession was the predicament of their opponents, since large states needed union less than small states and held the upper hand in a test of wills. In a more conciliatory vein, promises were tendered suggesting that large states would shed their domains and become small over time, and that small states had only to wait for equality to arrive.

But besides these reasons of a practical nature, the nationalists presented an argument that no fair-minded person could resist, or so they believed. People, not states, should be represented in the legislature, because people can be coerced by law, whereas states can only be coerced by war. Law operates equally on individuals, who in turn operate on government by voting equally for its lawmaking officials. But equal individuals vote in states of unequal size; accordingly, the representation of states should reflect that inequality so as to preserve the equality of persons.

As compelling as that argument might seem, it failed to impress the smallstate delegates who had an interest to defend in equal state representation. ${ }^{41}$

41. Besides the small-state interest in equal representation, two other factors (outside the scope of this article) were also in play, breaking the Convention along North-South and EastWest lines. These were slavery and new states. Proportional representation, even when confined to one chamber only, made slavery a national issue (it was not under the Articles of Confederation, where states voted equally). The three-fifths formula for counting slaves in the represented population increased southern representation at the expense of northern representation and incentivized the importation of new slaves. While no Convention delegate explicitly opposed or supported proportionality on grounds that it advantaged the South, or that it gave the North a legitimate interest in the South's affairs, several delegates, following Madison's lead (June 30, Farrand 1966-87, 1:486-87), did pick up on the connection (Paterson, July 9, 1:561; King and C. C. Pinckney, July 10, 1:566-67; Morris, July 13, 1: 601-2). Madison sensed early the damage that connecting these issues might do to the large-state coalition and directed the discussion elsewhere (May 30, 1:35-36). Morris, always less cautious, tied these issues together, hinting at the trouble that northern majorities, proportionally represented, might cause for southern slavery (July 7, 1:552). Even so, among the nationalists, only King and Morris expressed second thoughts about supporting proportionality (July 9, 1:562; July 13, 1:604), and for that their votes did not change (July 16, 2:15; see also Rakove 1987, 451; Zagarri 1987, 76-80). As for new, western states, their admission threatened to upset the current balance of eight northern and five southern states. Southerners generally welcomed new states, expecting them to come initially from the South, while northerners generally worried that westward migration would depopulate their region. With the Convention still in the throes of the Senate-representation debate, King reported on work in the Confederation Congress: that by one of its ordinances, the northwest country was to be partitioned ("impoliticly") into 10 territories, each admitted into the Union upon reaching a population equal to the smallest of the original states-which was Delaware's at 35,000 and that these new states might contain a combined population no larger than Pennsylvania's while enjoying voting power 10 times as great (July 6, 1:541). King's purpose, presumably, was to circumvent the North-South divide by giving the Atlantic states a common rival in the 
In the face of this small-state intransigence, nationalists had three options: to stand by their convictions and risk having the Convention fail, to adopt one of the several compromises floated by their colleagues, or to capitulate to the opposition. They chose the first option, only to see their coalition dissolve, and coming late to the second option, they had the third option forced on them.

More, though, was at work than miscalculation and bad timing. For, in fact, their argument of seemingly self-evident truth suffered from two fatal defects. The framers - whether nationalists or confederalists - were not instituting a democracy based solely on egalitarian principles. The regime being founded was rather a republic that compounded respect for majority rule with protections for minority rights. ${ }^{42}$ And in this compound, the Senate's role was to function, at least in part, as the aristocratic/oligarchic check on the democratic House. That being so, no obvious reason existed for organizing the upper house along lines of the lower house, with equal representation of persons and unequal representation of states. The second difficulty was that this new government aborning had not entirely severed ties to its confederal beginnings. Written into the Virginia Plan were openings for national lawmaking touching the states (e.g., the negative), and Convention debates added more openings still (e.g., direct taxation). In accordance with nationalist principle, parties subject to law must have a say in the making of law proportionate to the degree of subjection, which for the states meant equal representation. The only sure way then to remove states from subjection to national law, and thereby legitimately deny them their equal vote, was to remove states from the Union, the contemporary term for which was consolidation. The nationalists failed, finally, because in order to establish the justice of proportional representation, they needed to be consolidationists and democrats, and they were not quite either. ${ }^{43}$

West, but his observations failed to reset the debate. Otherwise, those northerners (and some southerners-Williamson, Rutledge) anxious about western expansion proposed denying new states full proportional representation in the House (e.g., Morris, July 5, 1:533). The effect of equal representation in the Senate was strangely not considered, except by King. Gerry once alluded to it (July 14, 2:3).

42. See Coby (2016) for a discussion of republics and mixed regimes as alternate modes of protecting minority rights and of the impact that each mode had on Convention debates.

43. It bears noting that the nationalists succeeded far more than they failed. They replaced a confederation of states with a hybrid union of people and states. They replaced a unicameral Congress, wholly the creature of the states, with a federal government partly national and partly (con)federal. They divided the federal government into three coequal branches and further divided the legislative branch into two chambers, one of which, the House, they based on proportional representation. Regarding the other chamber where equal representation obtained, the number of state senators was doubled (from one to two) and each senator accorded a separate vote, all were paid from the federal treasury, and their term was for 6 years. Provisions such as these made the Senate somewhat less the representative body of the states (see Martin, July 23, Farrand 1966-87, 2:94; Madison, June 26, 1:428; Ellsworth, August 14, 2:290; C. C. Pinckney, June 26, 1:421, 429) and so mitigated the two big nationalist losses on representation and mode of election. 


\section{REFERENCES}

Adams, Abigail Smith. 1975. The Book of Abigail and John: Selected Letters of the Adams Family, 1762-1784. Ed. L. H. Butterfield et al. Cambridge, MA: Harvard University Press.

Adams, John. 1977. The Papers of John Adams. Ed. Robert J. Taylor et al. Vol. 4. Cambridge, MA: Belknap.

Amar, Akhil Reed. 2005. America's Constitution: A Biography. New York: Random House.

Banning, Lance. 1983. "James Madison and the Nationalists." William and Marv Ouarterly 40 (2): 227-55.

-1987a. "The Constitutional Convention." In The Framing and Ratification of the Constitution, ed. Leonard W. Levy and Dennis J. Mahoney. New York: Macmillan.

_ 1987b. "The Practicable Sphere of a Republic: James Madison, the Constitutional Convention, and the Emergence of Revolutionary Federalism." In Beyond Confederation: Origins of the Constitution and American National Identity, ed. Richard Beeman, Stephen Botein, and Edward Carter. Chapel Hill: University of North Carolina Press.

- 1995. The Sacred Fire of Liberty: James Madison and the Founding of the Federal Republic. Ithaca, NY: Cornell University Press.

Beard, Charles. 1913. An Economic Interpretation of the Constitution of the United States. New York: Free.

Beeman, Richard. 2009. Plain, Honest Men: The Making of the American Constitution. New York: Random House.

Beer, Samuel H. 1993. To Make a Nation: The Rediscovery of American Federalism. Cambridge: Belknap.

Bilder, Mary Sarah. 2015. Madison's Hand: Revising the Constitutional Convention. Cambridge, MA: Harvard University Press.

Brant, Irving. 1948. James Madison: The Nationalist, 1780-1787. Indianapolis: BobbsMerrill.

Carey, George W. 1995. “James Madison and the Principle of Federalism.” In In Defense of the Constitution. Indianapolis: Liberty.

Coby, John Patrick. 2016. “The Long Road toward a More Perfect Union: Majority Rule and Minority Rights at the Constitutional Convention." American Political Thought 5 (1): 26-54.

Collier, Christopher, and James Collier. 1986. Decision in Philadelphia: The Constitutional Convention of 1787. New York: Ballantine.

Dahl, Robert A. 2003. How Democratic Is the American Constitution? 2nd ed. New Haven, CT: Yale University Press.

Diamond, Martin. 1959. "Democracy and The Federalist: A Reconsideration of the Framers' Intent." American Political Science Review 53 (1): 52-68.

- 1961. "What the Framers Meant by Federalism." In A Nation of States: Essays on the American Federal System, ed. Robert A. Goldwin. Chicago: Rand McNally.

Eidelberg, Paul. 1968. The Philosophy of the American Constitution: A Reinterpretation of the Intentions of the Founding Fathers. New York: Free.

Farrand, Max. 1966-87. The Records of the Federal Convention of 1787. Rev. ed. 4 vols. New Haven, CT: Yale University Press. 
Gibson, Alan. 2012. "Madison's 'Great Desideratum': Impartial Administration and the Extended Republic.” American Political Thought 1 (2): 181-207.

Goldwin, Robert A., and William A. Schambra. 1980. How Democratic Is the Constitution? Washington, DC: American Enterprise Institute.

Hendrickson, David C. 2003. Peace Pact: The Lost World of the American Founding. Lawrence: University Press of Kansas.

Hutson, James H. 1987. "Riddles of the Federal Constitutional Convention.” William and Marv Ouarterly 44 (3): 411-23.

Jefferson, Thomas. 1950. The Papers of Thomas Jefferson. Ed. Julian P. Boyd et al. Vol. 1. Princeton, NJ: Princeton University Press.

Jensen, Merrill. 1964. The Making of the American Constitution. Princeton, NJ: Princeton University Press.

Jillson, Calvin C. 1988. Constitution Making: Conflict and Consensus in the Federal Convention. New York: Agathon.

Jillson, Calvin C., and Cecil L. Eubanks. 1984. "The Political Structure of Constitution Making: The Federal Convention of 1787." American Journal of Political Science 28 (3): 435-58.

Klarman, Michael J. 2016. The Framers' Coup: The Making of the United States Constitution. Oxford: Oxford University Press.

Kramer, Larry. 1999. “Madison's Audience.” Harvard Law Review 112 (3): 611-79.

LaCroix, Alison L. 2010. The Ideological Origins of American Federalism. Cambridge, MA: Harvard University Press.

Madison, James. 1975. The Papers of James Madison. Ed. Robert Rutland et al. Vol. 9. Chicago: University of Chicago Press.

- 1977. The Papers of James Madison. Ed. Robert Rutland et al. Vol. 10. Chicago: University of Chicago Press.

Maier, Pauline. 2010. Ratification: The People Debate the Constitution, 1787-1788. New York: Simon \& Schuster.

Morris, Gouverneur. 2012. To Secure the Blessings of Liberty: Selected Writings of Gouverneur Morris. Ed. J. Jackson Barlow. Indianapolis: Liberty Fund.

Murrin, John M. 1988. “1787: The Invention of American Federalism.” In Essays on Liberty and Federalism: The Shaping of the U.S. Constitution, ed. John M. Murrin et al. College Station: Texas A\&M University Press.

Nelson, William E. 1987. "Reason and Compromise in the Establishment of the Federal Constitution, 1787-1801.” William and Marv Ouarterly 44 (3): 458-84.

Onuf, Peter S. 1988. "Constitutional Politics: States, Sections, and the National Interest." In Toward a More Perfect Union: Six Essays on the Constitution. Ed. Neil L. York. Provo, UT: Brigham Young University.

— 1989. "Reflections on the Founding: Constitutional Historiography in Bicentennial Perspective." William and Marv Ouarterlv 46 (2): 341-75.

Rakove, Jack N. 1979. The Beginnings of National Politics: An Interpretive History of the Continental Congress. New York: Knopf.

- 1987. "The Great Compromise: Ideas, Interests, and the Politics of Constitution Making." William and Marv Ouarterlv 44 (3): 424-57.

-1996. Original Meanings: Politics and Ideas in the Making of the Constitution. New York: Knopf.

Robertson, David Brian. 2005a. The Constitution and America's Destiny. Cambridge: Cambridge University Press. 
- 2005b. "Madison's Opponents and Constitutional Design." American Political Science Review 99 (2): 225-43.

Roche, John P. 1961. "The Founding Fathers: A Reform Caucus in Action.” American Political Science Review 55 (4): 799-816.

Rossiter, Clinton. 1966. 1787, The Grand Convention. New York: Norton.

Slonin, Shlomo. 2000. "Securing States' Interests at the 1787 Constitutional Convention: A Reassessment." Studies in American Political Development 14 (Spring): 1-19.

Smith, J. Allen. 1965. The Spirit of American Government. Cambridge, MA: Harvard University Press.

Storing, Herbert. 1983. "The Constitutional Convention: Toward a More Perfect Union." In American Political Thought: The Philosophic Dimensions of American Statesmanship, ed. Morton J. Frisch and Richard G. Stevens. Itasca, IL: Peacock.

Tate, Adam. 2013. "James Madison and State Sovereignty." American Political Thought 2 (2): 174-97.

Wirls, Daniel. 2003. "Madison's Dilemma: Revisiting the Relationship between the Senate and the 'Great Compromise' at the Constitutional Convention." In James Madison: The Theory and Practice of Republican Government, ed. Samuel Kernell. Stanford, CA: Stanford University Press.

Wolfe, Christopher. 1977. "On Understanding the Constitutional Convention of 1787." Lournal of Politics 39 (1): 97-118.

Wood, Gordon. 1969. The Creation of the American Republic, 1776-1787. Chapel Hill: University of North Carolina Press.

Yarborough, Jean. 1987. "Madison and Modern Federalism." In How Federal Is the Constitution, ed. Robert A. Goldwin and William A. Schambra. Washington, DC: American Enterprise Institute.

Zagarri, Rosemarie. 1987. The Politics of Size: Representation in the United States, 1776-1850. Ithaca, NY: Cornell University Press.

Zuckert, Michael P. 1986. "Federalism and the Founding: Toward a Reinterpretation of the Constitutional Convention." Review of Politics 48 (2): 166-210.

- 1987. "A System without Precedent: Federalism in the American Constitution." In The Framing and Ratification of the Constitution, ed. Leonard W. Levy and Dennis J. Mahoney. New York: Macmillan. 